\title{
Factors that Determine the Corporate Image of South African Fast Food Restaurants
}

\section{H van Heerden, A N Schreuder and M Gouverneur}

Department of Marketing and Communication Management, University of Pretoria

\begin{abstract}
Current operating practices of small businesses indicate that more time is devoted to the cosmetic side of corporate identity than managing service delivery. The main argument pursued in this paper is based on the view that both visual and behavioural corporate identity cues create impressions in the minds of corporate publics to form an overall corporate image. A set of bipolar adjectives was therefore used to test various visual, behavioural and core product elements of restaurant corporate image. A key finding was made that the joint customer service and employee dimension, was rated as the most important factor in the choice of fast food restaurants, which confirms that corporate image is created by visual and behavioural identity.
\end{abstract}

JEL M 37

\section{INTRODUCTION}

There are different views on what the concept of corporate identity actually means. One of the most popular myths is that corporate identity consists only of visual elements such as a well-known corporate name, a distinctive corporate logo and attractive corporate colours (Van Heerden, 1994).

Although these elements do initially attract the customer, it is the corporate personality, which consists of a diverse set of behavioural and visual elements, that creates or breaks long-term relationships with customers. Another important point that all managers should take note of is that this set of behavioural elements creates perceptions in the minds of customers which lead to the formation of an overall corporate image. In other words, an attractive logo and well-designed corporate stationary will not compensate for unfriendly customer service or bad employee morale. 


\section{PROBLEM STATEMENT}

The main argument pursued in this paper is based on the view of Van Heerden $(1999,492)$ that "both visual and behavioural corporate identity cues create impressions or perceptions in the minds of corporate audiences to form an overall corporate image".

Selected restaurants from the fast food industry in South Africa were investigated, with specific emphasis on identifying different cues that represent both the visual and behavioural elements of their corporate identity.

The following hypotheses were tested:

$H_{1}$ : Respondents who indicate high levels of visual identity, have significantly more positive general impressions of the fast food restaurants than respondents who indicate a low level of visual identity.

$\mathrm{H}_{2}$ : Respondents who indicate high levels of behavioural identity (e.g. customer service), have significantly more positive general impressions of a fast food restaurant than respondents who indicate a low level of behavioural identity.

$H_{3}$ : Respondents who have a high opinion of the core product ingredients (food \& drink), have significantly more positive general impressions of that fast food restaurant than respondents who have a low opinion of the core product.

$H_{4}$ : Respondents who have a high combined opinion of the behavioural and visual identity of a fast food restaurant, have a significantly more favourable impression of that fast food restaurant than those respondents who have a low combined opinion of the behavioural and visual identity of that fast food restaurant.

\section{LITERATURE REVIEW}

\subsection{The Nature of Corporate Identity and Corporate Image}

There are many authors who have different views on what corporate identity and corporate image are, and how they influence one another (Barnard, 1991:4; Drummond, 1995: 9; Sampson, 1995: 36; Stewart, 1991: 32; and Miller, 1990: 30).

Carter (1982: 8) states that corporate image is the way a corporation is perceived through the eyes of its various audiences, while corporate identity is that part of the image which can be seen or heard. These images are usually the 
first impressions created in the minds of customers when they are exposed to corporate identity cues.

Croft (1989: 65) argues that the corporate identity is the total personality of an organisation as perceived by its audiences, and not only the visual aspects. It is also a statement of how a company is organised and run, how its products and services are being managed, and where the company is going.

\subsection{Visual and Behavioural Elements of the Corporate Identity}

Every business has a particular image by virtue of its external appearance, internal layout or even the way they do things, and it is therefore important to ensure that a positive message is being conveyed to the consumer.

Research indicates that customers greatly value consistency and reliability in service delivery (Croft 1989: 65). Thus, when all competitors in a specific service sector deliver a similar core product, for example fast food, the evaluation of supplementary services and corporate identity would become some of the differentiating factors on which customers base their initial purchase choice and even later repeat business.

Corporate identity is therefore concerned with expressing three interrelated themes, namely, coherence, symbolism and positioning/differentiation:

- First, the corporation wants its various parts (business units, operations and product/service output) to relate to each other so that people can find their way around its divisions, corporations, and brands - that is, coherence;

- Second, the corporation wants to symbolise its vision and mission so that everyone who works for it can share the same spirit, and then communicate it positively to all other people who deal with the corporation - symbolism; and

- Third, the corporation wants to differentiate itself and its products (food and drink) or services (speed of delivery) from those of its competitors in the market place - positioning.

These three themes - coherence, symbolism, and positioning - relate to the very core of a corporation (Olins 1987: 87) and serve to focus the corporate strategy.

When analysing existing corporate identity models (Abratt, 1989; Burrows, 1991; and Skinner \& Von Essen, 1991), certain general assumptions can be made: 
- Corporate personality, identity and image are elements of an ongoing cyclical process.

- Corporate identity should be aimed at all the publics of the corporation.

- The implementation of the corporate identity strategy is done via visual and behavioural elements.

Grönroos (1992: 39) feels that corporate image is a third dimension of service quality. The corporate image can therefore be expected to be reinforced by the technical quality of the service (what the consumer receives in the service) and its functional quality (how the consumer receives the service).

Since services are inseparable from the provider, visual imagery plays an important role in the perceived quality of service delivery. Prescribed elements are built around the core products to represent value-added supplementary services, which leads to another important factor in the image making process that of customer service (Lovelock, 1996: 343). Because service quality is so difficult to judge, corporations should take great care to keep quality consistent. A logo or trademark can thus even serve as a symbol that the service is of a certain standard.

Thus full service providers such as fast food restaurants must concentrate on linking their brands with the core values of trust, honesty and integrity, while listening closely to what each individual wants and offering value for money.

For services to grow and prosper, they must build new and lasting relationships with new customers, go back to basics and offer reliability, responsiveness, honesty, empathy and tangible proof of the organisation's commitment to quality service (Denby-Jones 1995: 66).

The arguments of the above-mentioned experts underscore that corporate identity is internally generated by corporate strategy, but the corporate image is externally located as perceptions in the minds of corporate publics such as suppliers and customers.

\section{METHODOLOGY}

\subsection{Introduction}

The focus of this study is on the relationship between the corporate logos of selected fast food restaurants and the perception customers have of these 
companies. Therefore not all aspects of the corporate identity have been covered in the investigation.

The variables tested were the following:

- Visual elements - Independent variable

- Behavioural elements - Independent variable

- Core product - Independent variable

- General impression - Dependent variable

The reasons why South African fast food restaurants (as research subjects) and university students (as respondent group) were chosen are that:

- Fast food restaurants are highly visible and geographically dispersed.

- Fast food restaurants are widely used by different age groups (of which students represent a significant target segment).

- Competition between the companies is fierce, because of the vast number of consumers and the increased entry of international firms (such as McDonald's) after political change - which led to a higher awareness of their existence in South Africa.

- Advertising and sponsorships occur frequently in the fast food industry. Thus a fair amount of exposure is produced.

- All fast food restaurants have distinguishable logos and corporate symbols.

- Most of the respondents (students) have either visited the selected fast food outlets or been exposed to marketing communication efforts such as advertisements and sales promotions.

\subsection{Research Design}

\subsubsection{Data collection and sample selection and size}

This was an exploratory investigation where quantitative measures (selfadministered questionnaires) were used. The following sampling approach was taken:

- Convenience sampling since students who attend marketing and communication management classes were easily accessible.

- A sample of 200 respondents completed the questionnaire.

\subsubsection{Instrumentation procedures}

A structured self-completion questionnaire was used which consisted of:

- A set of bipolar items generated and refined to represent a semantic differential scale. 
- Respondent perceptions were cued through a specific concept/construct the corporate logo (a full colour copy of each logo was shown to the students on an overhead projector).

- Respondents were then expected to rate their perceptions of every fast food restaurant on each of the bipolar items included in the semantic scale while viewing a specific corporate logo.

- Method of data collection:

$>$ Respondents were asked for their first impression of or immediate reaction to the logo of the fast food restaurant being measured.

$>$ Respondents then indicated their impressions by selecting a position along a scale bounded by bipolar adjectives.

$>$ A repeated measure design was used, since respondents had to repeat the same process for each of the fast food restaurants.

- Subsequent data and statistical analysis was done with the aid of CSS STATISTICA. Techniques such as factor analysis, correlation and ANOVA were used to identify the number of factors that determined the corporate image of these companies.

Table 1 Bipolar adjectives used to measure the core product $(C)$, visual $(V)$ and behavioural $(B)$ elements of corporate identity

\begin{tabular}{|l|c|r|c|}
\hline \multicolumn{4}{|c|}{ Bipolar Adjectives for Core product } \\
\hline Expensive & vs & Inexpensive & C \\
\hline Tasteful & vs & Tasteless & C \\
\hline Low quality & vs & High quality & C \\
\hline Healthy & vs & Unhealthy & C \\
\hline Extra value & vs & No extra value & C \\
\hline Inconvenience & vs & \multicolumn{3}{|c|}{ Convenience } & C \\
\hline Bipolar Adjectives for Behavioural elements of Corporate Identity \\
\hline Dishonest & vs & \multicolumn{3}{|r|}{ Honest } & B \\
\hline Friendly & vs & Unfriendly & B \\
\hline Likeable & vs & Unlikeable & B \\
\hline Bad service & vs & Good service & B \\
\hline Reputable & vs & Disreputable & B \\
\hline Unsuccessful & vs & Successful & B \\
\hline Unhelpful staff & vs & Helpful staff & B \\
\hline Irresponsible & vs & Responsible & B \\
\hline
\end{tabular}




\section{Table 1 continued}

\begin{tabular}{|l|c|r|c|}
\hline \multicolumn{4}{|c|}{ Bipolar Adjectives for Visual elements of Corporate Identity } \\
\hline Well known & vs & Unknown & V \\
\hline Interesting & vs & Boring & V \\
\hline Unattractive & vs & Attractive & V \\
\hline Clean & vs & Dirty & V \\
\hline Unbelievable ads & vs & Believable ads & V \\
\hline Busy & vs & Lazy & V \\
\hline
\end{tabular}

\section{FINDINGS}

\subsection{Descriptive Statistics}

All descriptive statistics took reverse scaling into account. Reverse scaling was required since the adjective pairs had different directions of positive and negative order. This made direct comparison of adjective pairs easier. The results are summarised in Table 2.

In order to determine the effect of the visual and behavioural elements and the core product-evaluation on the general impression of the restaurants, a combined mean had to be calculated for each independent variable. The following observations can be made from Table 2:

- The highest adjective variable was "Well-known/Unknown" (4.646), whilst "Successful/Unsuccessful" (4.141) also showed a high mean score.

- The lowest adjective variables was "Expensive/Inexpensive" (2.905), with the closely related variable "Extra value/ No extra value" (3.126) also with a fairly low mean score.

- On combined means the core product variables were the most favourable (3.394) and the behavioural variables the least favourable (3.729). It must be noted though that the variance between the combined means is too small to make any conclusive findings. 
Table 2 The Mean and Standard deviation of each independent variable

\begin{tabular}{|l|c|c|}
\hline \multicolumn{1}{|c|}{ Category } & Mean & $\begin{array}{c}\text { Standard } \\
\text { deviation }\end{array}$ \\
\hline \multicolumn{1}{|c|}{ Visual Variables } & & \\
\hline Well-known/Unknown & 4.646 & 0.667 \\
\hline Interesting/ Boring & 3.480 & 1.036 \\
\hline Unattractive/ Attractive & 3.688 & 0.913 \\
\hline Clean/Dirty & 3.764 & 0.942 \\
\hline Believable ads/Unbelievable ads & 3.404 & 1.076 \\
\hline Busy/Lazy & 3.772 & 0.939 \\
\hline Combined Mean & 3.792 & \\
\hline \multicolumn{1}{|c|}{ Behavioural variables } & & \\
\hline Honest/Dishonest & 3.805 & 0.896 \\
\hline Friendly/Unfriendly & 3.635 & 0.964 \\
\hline Likeable/Unlikeable & 3.770 & 1.000 \\
\hline Good service/Bad service & 3.659 & 0.957 \\
\hline Reputable/Disreputable & 3.653 & 0.900 \\
\hline Successful/Unsuccessful & 4.141 & 0.913 \\
\hline Helpful/Unhelpful & 3.548 & 0.974 \\
\hline Responsible/Irresponsible & 3.625 & 0.865 \\
\hline Combined Mean & 3.729 & \\
\hline \multicolumn{1}{|c|}{ Core product } & & \\
\hline Expensive/Inexpensive & 2.905 & 1.233 \\
\hline Tasteful/Tasteless & 3.826 & 1.043 \\
\hline High quality/Low quality & 3.613 & 0.966 \\
\hline Healthy/Unhealthy & 3.141 & 1.003 \\
\hline Extra value/ No extra value & 3.126 & 1.070 \\
\hline Convenience/Inconvenience & 3.750 & 0.916 \\
\hline Combined Mean & 3.394 & \\
\hline
\end{tabular}




\section{Figure 1 Overall impression of respondents on four fast food restaurants}

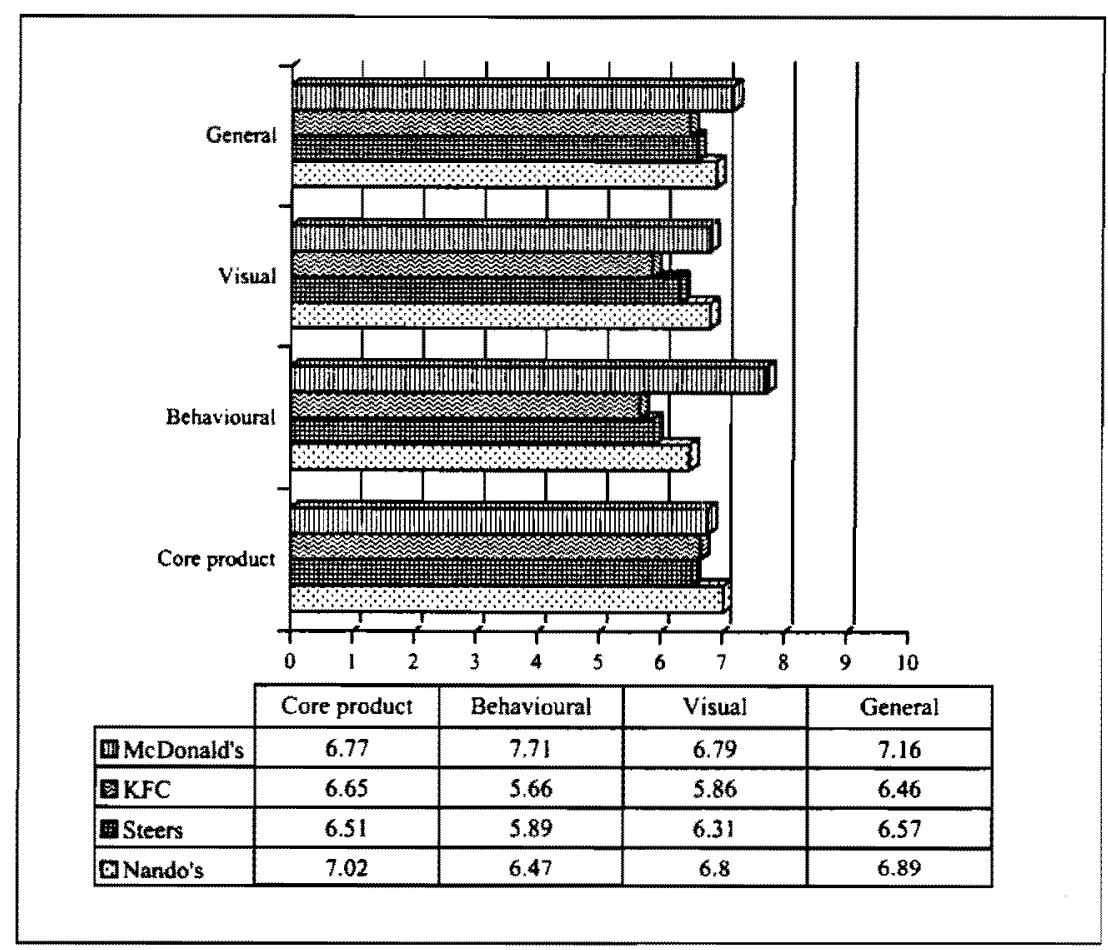

The effects of current corporate identities of the four fast food restaurants can clearly be seen from Figure 1, with particular refererence to:

- McDonald's achieved the best general impression amongst respondents, which is supported by the high score on both the visual and behavioural elements of their corporate identity.

- Nando's received the best score on core product evaluation, and scored a close second to McDonald's in all other areas.

\subsection{Analytical Statistics}

\subsubsection{Reliability analysis}

A reliability analysis enables the researcher to test the consistency or stability of a measured quantity (Cooper \& Emory, 1995:153), that is, to calculate an index that registers the extent to which measured data are free from random error. If all items were perfectly reliable and measured the same true score, the coefficient alpha would be equal to 1 . 
The total alpha-value of the instruments was 0.904 , which is regarded as a significantly reliable coefficient. Once the overall reliability of the instrument had been established, it was necessary to determine whether sufficient variance existed between the different fast food restaurants evaluated in this study.

To demonstrate that the perception of the tested fast food restaurants differed from one another, the following significant differences in Table 3 were determined with ANOVA. All responses with a p-value smaller than 0.05 were regarded as having a significant difference in perception.

From Table 3 it can be concluded that, with two exceptions, all adjective pairs showed significant differences $(p<0.05)$ between the restaurants measured. The exceptions are:

- Extra value / No extra value $(\mathrm{p}=0.257)$ and Good service / Bad service $(p=0.474)$ where $p>0.05$. There are therefore no significant differences, concerning value-added or service level, between the restaurants measured in this study.

Table 3 Significant differences between the fast food restaurants

\begin{tabular}{|c|c|c|c|c|c|c|}
\hline Category & Nando's & Steers & KFC & $\begin{array}{l}\text { McDo- } \\
\text { nald's }\end{array}$ & $\begin{array}{c}\text { F- } \\
\text { value }\end{array}$ & p-value \\
\hline \multicolumn{7}{|c|}{ Visual Variables } \\
\hline $\begin{array}{l}\text { Well known / } \\
\text { Unknown }\end{array}$ & 4.47 & 4.68 & 4.81 & 4.64 & 8.309 & 0.000 \\
\hline Interesting / Boring & 3.69 & 3.27 & 3.18 & 3.79 & 16.689 & 0.000 \\
\hline $\begin{array}{l}\text { Unattractive / } \\
\text { Attractive }\end{array}$ & 3.85 & 3.57 & 3.52 & 3.82 & 7.068 & 0.000 \\
\hline Clean / Dirty & 3.84 & 3.53 & 3.46 & 4.24 & 28.171 & 0.000 \\
\hline \multicolumn{7}{|l|}{ Visual Variables } \\
\hline $\begin{array}{l}\text { Believable advertise- } \\
\text { ments/ Unbelievable } \\
\text { advertisements }\end{array}$ & 3.71 & 3.34 & 3.08 & 3.50 & 12.249 & 0.000 \\
\hline Busy / Lazy & 3.67 & 3.71 & 3.54 & 4.17 & 17.088 & 0.000 \\
\hline \multicolumn{7}{|c|}{ Behavioural variables } \\
\hline Honest / Dishonest & 3.92 & 3.68 & 3.70 & 3.93 & 4.400 & 0.004 \\
\hline $\begin{array}{l}\text { Friendly / } \\
\text { Unfriendly }\end{array}$ & 3.74 & 3.20 & 3.44 & 4.17 & 24.326 & 0.000 \\
\hline
\end{tabular}


Table 3 continued

\begin{tabular}{|l|c|c|c|c|c|c|}
\hline Category & Nando's & Steers & KFC & $\begin{array}{c}\text { McDo- } \\
\text { nald's }\end{array}$ & $\begin{array}{c}\text { F- } \\
\text { value }\end{array}$ & p-value \\
\hline $\begin{array}{l}\text { Likeable / } \\
\text { Unlikeable }\end{array}$ & 3.57 & 3.36 & 3.21 & 4.07 & 29.589 & 0.000 \\
\hline $\begin{array}{l}\text { Good service / Bad } \\
\text { service }\end{array}$ & 3.84 & 3.70 & 3.74 & 3.81 & 0.836 & 0.474 \\
\hline $\begin{array}{l}\text { Reputable / } \\
\text { Disreputable }\end{array}$ & 3.75 & 3.32 & 3.31 & 4.26 & 44.200 & 0.000 \\
\hline $\begin{array}{l}\text { Successful / } \\
\text { Unsuccessful }\end{array}$ & 3.66 & 3.53 & 3.59 & 3.84 & 4.365 & 0.005 \\
\hline $\begin{array}{l}\text { Helpful/ } \\
\text { Unhelpful }\end{array}$ & 4.15 & 4.03 & 4.03 & 4.37 & 6.073 & 0.000 \\
\hline $\begin{array}{l}\text { Responsible / } \\
\text { Irresponsible }\end{array}$ & 3.67 & 3.60 & 3.45 & 3.79 & 5.383 & 0.001 \\
\hline & 2.84 & 3.02 & 2.65 & 3.12 & 5.641 & 0.001 \\
\hline $\begin{array}{l}\text { Expensive / } \\
\text { Inexpensive }\end{array}$ & 3.34 & 3.02 & 3.06 & 3.15 & 3.902 & 0.009 \\
\hline Tasteful / Tasteless & 4.00 & 3.80 & 3.91 & 3.60 & 5.352 & 0.001 \\
\hline $\begin{array}{l}\text { High quality /Low } \\
\text { quality }\end{array}$ & 3.79 & 3.53 & 3.58 & 3.56 & 2.881 & 0.035 \\
\hline $\begin{array}{l}\text { Healthy } \\
\text { Unhealthy }\end{array}$ & 3.08 & 3.04 & 3.23 & 1.349 & 0.257 \\
\hline $\begin{array}{l}\text { Extra value / No } \\
\text { extra value }\end{array}$ & 3.17 & 3.68 & 3.67 & 3.98 & 5.362 & 0.001 \\
\hline $\begin{array}{l}\text { Convenience / } \\
\text { Inconvenience }\end{array}$ & 3.68 & Core product & & & \\
\hline
\end{tabular}

\subsubsection{Factor analysis}

Factor analysis assesses the interrelations among a large set of variables, to reduce a large number of responses to a smaller more basic set of hypothetical variables called factors (Smith 1988:167). A principal component factor analysis was performed with a normalised Varimax rotation. The eigenvalue $<1$ criterion was used for identifying a four-factor solution. The factor loading for the four-factor solution is illustrated in Table 4. 
Table 4 Four-factor solution for corporate identity variables of fast food restaurants

\begin{tabular}{|l|c|c|c|c|}
\hline Variable & Factor 1 & Factor 2 & Factor 3 & Factor 4 \\
\hline Good service/ Bad service (B) & 0.816 & & & \\
\hline Helpful staff/ Unhelpful (B) & 0.810 & & & \\
\hline Clean / Dirty (V) & 0.712 & & & \\
\hline Friendly/ Unfriendly staff (B) & 0.698 & & & \\
\hline Irresponsible/ Responsible (B) & 0.535 & & & \\
\hline Busy / Lazy (V) & 0.534 & & & \\
\hline Interesting / Boring (V) & 0.533 & & & \\
\hline Tasteless/ Tasteful (C) & & 0.807 & & \\
\hline High quality/ Low quality (C) & & 0.748 & & \\
\hline Unlikeable/ Likeable (B) & & 0.611 & & \\
\hline Unhealthy / Healthy (C) & & 0.552 & & \\
\hline Expensive / Inexpensive (C) & & & 0.828 & \\
\hline No extra value / Extra value (C) & & & 0.540 & \\
\hline Unknown / Well known (C) & & & & 0.834 \\
\hline Successful / Unsuccessful (B) & & & & 0.616 \\
\hline Eigenvalue & $\mathbf{7 . 0 4 8}$ & $\mathbf{1 . 3 7 9}$ & $\mathbf{1 . 1 3 5}$ & $\mathbf{1 . 1 1 2}$ \\
\hline $\begin{array}{l}\text { Cumulative \% of variance } \\
\text { explained }\end{array}$ & $\mathbf{3 5 . 2 4 \%}$ & $\mathbf{4 2 . 1 3 \%}$ & $\mathbf{4 7 . 8 0 \%}$ & $\mathbf{5 3 . 3 6 \%}$ \\
\hline
\end{tabular}

The following variables were not included because their loading were below 0.05 :

Honesty (B), Reputation (B), Attractiveness (V), Believability of advertisements $(V)$ and Convenience $(C)$

Although the factors are not entirely visual, behavioural and core representative, there is still sufficient evidence of these variables amongst the suggested factor solution. The underlying factors could then be classified as:

Factor 1: Behavioural identity - A descriptive expression for this factor is at first glance rather difficult. One half of the adjective variables that were included in this factor were originally classified as behavioural and the other half as visual. The inclusion of "dirty/clean", "busy/lazy" and "interesting/boring" can all be seen as tangible evidence of various behavioural issues, and as such could be part of a behavioural identity descriptor. Finally, it was decided to describe this factor as a "behavioural identity" since the factor loading of the original behavioural variables was higher than the factor loading of those variables originally classified as visual. 
This factor thus represents the way customers are treated and the way employees and the organisation as a whole behave.

Factor 2 Core product image - The adjective variables included in this factor would best describe product related issues such as taste, quality and healthiness.

Factor 3 Core value image - This factor relates to value in terms of expensiveness and value for money.

Factor 4 Visual recognition - This factor relates to the way customers recognise visual cues such as the corporate logos and buildings.

Table 5 Correlation between visual, behavioural and core attributes

\begin{tabular}{|l|c|c|}
\hline \multicolumn{1}{|c|}{ Item-Behavioural } & Item-Visual & Score \\
\hline Friendly/ Unfriendly & Dirty/Clean & 0.507 \\
\hline Good service/ Bad service & Dirty/Clean & 0.541 \\
\hline Helpful staff/ Unhelpful & Dirty/Clean & 0.525 \\
\hline
\end{tabular}

It is important to note that the hygiene factor (dirty/clean) occurs in each correlated situation. Thus the visual effect of cleanliness correlates positively with the behaviour and customer service levels of the employees. This is one of the most important findings of this study: customer service and employee behaviour was rated as the most important factor in the choice of fast food restaurants, which confirms that corporate image is created by visual and behavioural identity cues.

\section{RESULTS AND CONCLUSIONS}

The stated hypotheses were tested by using ANOVA, which allows the researcher to test group differences that are attributable to a single independent variable. It also allows testing for significance (Smith 1988: 130). Table 6 contains a summary of the test statistics used in the ANOVA, as well as the acceptance or rejection of the various stated hypotheses.

Whenever a specific variable was labelled as high, scale values equal to and larger than 3 on a scale from 1 to 5 were used. Consequently low levels on all independent variables were tested on scale values of less than 3 on a 5-point scale. All dependent variables were analysed as mean scale values on a 0 to 10 scale. 
Table 6 Test statistics of ANOVA: Significance testing

\begin{tabular}{|c|c|c|c|c|}
\hline Hypothesis 1 & & & & \\
\hline Independent & Dependent & Mean & P-value & Decision \\
\hline $\begin{array}{l}\text { Low level of visual identity } \\
\text { High level of visual identity }\end{array}$ & $\begin{array}{c}\text { General } \\
\text { impression }\end{array}$ & $\begin{array}{l}5.894 \\
7.862 \\
\end{array}$ & 0.0000 & $\begin{array}{lll}\begin{array}{l}\text { Accept } \\
\text { level }\end{array} & \text { at } & 99 \% \\
\end{array}$ \\
\hline \multicolumn{5}{|l|}{ Hypothesis 2} \\
\hline Independent & Dependent & Mean & P-value & Decision \\
\hline $\begin{array}{l}\text { Low level of behavioural } \\
\text { identity } \\
\text { High level of behavioural } \\
\text { identity }\end{array}$ & $\begin{array}{l}\text { General } \\
\text { Impression }\end{array}$ & $\begin{array}{l}5.956 \\
7.972\end{array}$ & 0.0000 & $\begin{array}{l}\begin{array}{l}\text { Accept } \\
\text { level }\end{array} \\
\text { at }\end{array}$ \\
\hline \multicolumn{5}{|l|}{ Hypothesis 3} \\
\hline Independent & Dependent & Mean & P-value & Decision \\
\hline $\begin{array}{l}\text { Low opinion of core products } \\
\text { High opinion of core products }\end{array}$ & $\begin{array}{l}\text { General } \\
\text { Impression }\end{array}$ & $\begin{array}{l}6.378 \\
8.257\end{array}$ & 0.0000 & $\begin{array}{l}\text { Accept at } 99 \% \\
\text { level }\end{array}$ \\
\hline \multicolumn{5}{|l|}{ Hypothesis 4} \\
\hline Independent & Dependent & Mean & P-value & Decision \\
\hline $\begin{array}{l}\text { Low combined level } \\
\text { High combined level }\end{array}$ & $\begin{array}{l}\text { General } \\
\text { Impression }\end{array}$ & $\begin{array}{l}5.944 \\
8.041\end{array}$ & 0.0000 & $\begin{array}{l}\text { Accept at } 99 \% \\
\text { level }\end{array}$ \\
\hline
\end{tabular}

$H_{1}$ Hypothesis result: $\quad$ Accept hypothesis at $99 \%$ level of significance that respondents who indicated high levels of visual identity, have significantly more positive general impressions of a fast food restaurant than respondents who indicated a low level of visual identity.

$\mathrm{H}_{2}$ Hypothesis result: Accept hypothesis at $99 \%$ level of significance that respondents who indicated high levels of behavioural identity, have significantly more positive general impressions of a fast food restaurant than respondents who indicated a low level of behavioural identity.

$\mathrm{H}_{3}$ Hypothesis result: $\quad$ Accept hypothesis at $99 \%$ level of significance that respondents who have a high opinion of the core product, have significantly more positive general impressions of a fast food restaurant than respondents who have a low opinion of the core product.

$\mathrm{H}_{4}$ Hypothesis result: Accept hypothesis at $99 \%$ level of significance that respondents who indicated a high combined level of behavioural and visual identity, have significantly more positive general impressions of the fast food 
restaurants than respondents who indicated a low combined level of behavioural and visual identity.

This study is at most an exploratory investigation into factors that determine the corporate identity of some fast food restaurants that operate in South Africa. Other specific limitations should also be noted:

- Only convenience sampling was done.

- The respondents used in this investigation (students) may not be representative of the South African population to make generalisations of the results possible.

- The list of bipolar items used in this semantic differential might have been more complete because the possibility exists that certain items were excluded or even overlapped. The use of semantic differentials may also have biased the instrument interpretation to different semantic meaning and understanding by various respondent subgroups.

- Not all fast food restaurants were tested in this study.

- The factors identified as contributing to corporate image may only be relevant to fast food restaurants and not to other industries.

- The relationship between the independent and the dependent variables were not investigated in more depth to determine the relative importance of the various independent variables.

\section{RESEARCH AND MANAGEMENT RECOMMENDATIONS}

Further research suggestions and management recommendations may be summarised as follows:

- Determine whether the corporate identity is more tangible or intangibledominant - this will eliminate any uncertainty whether the core product should also be tested.

- Focus more research on how the core product (food and drink) influences the corporate image.

- Create a more objective scale for the measurement of visual and behavioural elements. In this way a more clearly differentiated factor solution would emerge where separate factors for visual and behavioural identity could be found.

- Investigate the possibility to change the scale methodology to that of a Likert rating scale rather than a semantic differential scale. 
- Determine other visual and behavioural elements that could influence corporate image to enhance the measurement instrument.

- Perform regression type analysis to investigate the relationship between various independent variables and corporate image.

- Test the independent variables of corporate image on other dependent variables such as loyalty, repurchase or customer retention.

- Management should spend more time on aspects such as customer service levels and implementing appropriate management styles.

KEY FINDINGS AND CONCLUSION

The most important finding is that the joint customer service and employee dimension was rated as the most important factor in the choice of fast food restaurants, which confirms that corporate image is created by visual and behavioural identity.

The key findings can be summarised as follows:

- Visual identity plays an important role in establishing the perception of a fast food restaurant. A strong correlation between the visual and the behavioural elements was also found $\left(\mathrm{H}_{1} \& \mathrm{H}_{2}\right)$.

- The behavioural identity, also known as the customer service and employee dimension of corporate identity, was rated as the most important factor in the choice of fast food restaurants (factor analysis) and thus plays a vital role in establishing the general impression of a fast food restaurant $\left(\mathrm{H}_{2}\right)$.

- There was no significant difference in the way the respondents rated the core products of the fast food restaurants, but this factor definitely has an impact on the overall perception of a fast food restaurant $\left(\mathrm{H}_{3}\right)$. It is comparable to the factor of safety in the case of airlines.

- The combined effect of visual and behavioural elements is significantly higher than each variable by itself. It therefore provided strong evidence that corporate image consists of more than just visual elements, and the importance of behavioural elements should in fact be regarded tegether with the impact of visual identity $\left(\mathrm{H}_{4}\right)$.

This study thus leads to the conclusion that corporate behavioural traits also play a vital role in creating and maintaining a desired and positive corporate image. Since a fast food restaurant operates with both tangible and intangible elements, the core product itself and various aspects concerning it were also tested. This showed that the core product (e.g. hamburgers, chips, salads and cold drinks) plays an important role in forming overall general impressions. It is 
not yet conclusive though, whether all consumers regard the Steers burger better than the Big Mac of McDonald's.

The underlying intangible service delivery (e.g. speed of processing an order, friendliness of staff and speed of delivery) also plays an important role in supporting the tangible perceptions created by the core product. It is still inconclusive to what extent good service delivery can support a lower quality product before consumers switch their loyalty to a competing product.

\section{REFERENCES}

1 ABRATT, R. (1989) "A new approach to the Corporate Image Management Process", Journal of Marketing Management. 5(1): 63-76.

2 BARNARD, J. (1991) "Marketing your Business through Corporate Image", Marketing Management, 2(11): 4-5.

3 BURROWS, M.M. (1991) "Strategies on the Marketing of Intangibles with special Reference to Corporate Image", Paper read at the Westem Cape Marketing Educators' National Conference, November.

4 CARTER, D.E. (1982) Designing Corporate Identity Programs for Small Corporations, New York: Art Direction Book Co.

5 COOPER, D.R. and EMORY, C.W. (1995) Business Research Methods, Fifth ed., IRWN: America.

6 CROFT, M. (1989) "Beyond the Corporate Logo", Accountancy, Aug: 65-66.

7 DENBY-JONES, S. (1995) "Mind the Gap", The Banker, Feb: 66-67.

8 DRUMMOND, G. (1995) "Corporate Branding Focuses on Service", Below the Line, Oct: 9.

9 GRÖNROOS, C. (1984) "A Service Quality Model and its Marketing Implications", European Journal of Marketing, 18(4): 36-44.

10 LOVELOCK, C. H. (1996) Services Marketing, Third ed., Prentice Hall International.

11 MILLER, K. D. (1990) "Building a Corporate ID", Black Enterprise, $5(10): 30-32$.

12 OLINS, W. (1987) The Corporate Personality, Mayflower Books Inc. New York.

13 SAMPSON, J. (1995) "Shining Through: Corporate branding under the Spotlight", Marketing Mix, 13(4): 36-7.

14 SMITH, M.J. (1988) Contemporary Communication Research Methods, Wadsworth: Belmont.

15 SKINNER, C. and VON ESSEN, L. (1991) The Handbook of Public Relations, Third ed., Southem Book Publishers, Halfway House, South Africa. 
16 STEWART, K. (1991) "Corporate Identity: A Strategic Marketing Issue, Journal of Bank Marketing, 9(1): 32-9.

17 VAN HEERDEN, N. (1994) "There is more to Corporate Image than Meets the Eye, Image \& Text - A Journal for Design, 4, December: 3-8.

18 VAN HEERDEN, C. H. (1999) "Developing a Corporate Image Model", South African Journal of Economic and Management Sciences. 2(3), September: 492-508. 